\title{
Azerbaijan is in the TANAP, TAP, and South Stream Project Triangle at the Deadlock of Nabucco
}

\author{
Osman SÖNMEZ \\ Selçuk University, Konya, Turkey \\ Elnur Hasan MİKAİL, Cihan KÜCÜKYILDIZ \\ Kars Kafkas University, Kars, Turkey \\ TURAN-CSR, Kars, Turkey
}

\begin{abstract}
This study has been investigated some pipeline lines after collapsing process of Union of Soviet Socialist Republics from Azerbaijan to Europe and another alternative ways from Russia. As we know Russia is a big power as from economic, defensive, and political aspects, as that's in ruler position in the region. So, USA from another side of the world as a super power of the world could make dimension of those pipelines from transit of Turkey. That's why new Nabucco project has been also cancelled by Russia's power. This article has been studied newly established project of Trans Anatolian Natural Gas Line Project (TANAP) from Azerbaijan's oil and gas department, Ministry's State Petroleum Company's (SOCAR) project has not been cancelled by Turkish Petroleum Company (TPAO). So TANAP's advantages and disadvantages have been researched in this article.
\end{abstract}

Keywords: Azerbaijan, Nabucco, Russia, State Petroleum Company (SOCAR), Trans Anatolian Natural Gas Line Project (TANAP), Turkey, USA

\section{Introduction}

The famous French writer Claude Farrére was writing those for Cengiz Han: "The wonderful human, who conquered Mongolia, Russia, Poland, half of China, Iran, some part of Europe and half of the Anatolia, was appointing secondary officers for this job. He himself was interested in transport roads and general order" (Farrére, 2001, p. 163). The transport roads, which were compulsory for conquering countries in the era of Cengiz Han, have gained vital importance for trade in subsequent periods.

It has been mentioned in the sources that the big road of the Silk Road was called the King Road, where merchants and caravans from every nation pass through, being referred as et-Tarîku'l-Harîr in Arabic sources, as Great Silk Road in English works, as Jamb in Mongolian. The Silk Road is the biggest one among historical main roads used by large caravans for long times on the earth, by connecting to large trade roads referred with different names at south and north

Osman SÖNMEZ, Ph.D., Assistant Professor, Department of Atatürk Principles and Reforms Application Center, Selçuk University.

Elnur Hasan MİKAIIL, Ph.D., Assistant Professor, Department of Political Sciences and Public Administration, Faculty of Economics and Administrative Sciences, Kars Kafkas University; Founder and President of TURAN-CSR (TURAN-SAM).

Cihan KÜCÜKYILDIZ, Bachelor's Student, Department of Political Sciences and Public Administration, Faculty of Economics and Administrative Sciences, Kars Kafkas University; Vice President of TURAN-CSR (TURAN-SAM).

Correspondence concerning this article should be addressed to Elnur Hasan MIKKAİL, Department of Political Sciences and Public Administration, Faculty of Economics and Administrative Sciences, Kars Kafkas University, Kars, Turkey. E-mail: emikail@turansam.org. 
directions. (Kirpik, 2012, p. 174)

Those who controlled this road had dominated both East and West for many years as in the example of Ottomans.

We come across the Road again with regard to the superiority of West over East. The Western States particularly Portugal, Spain, England, and France, which could not go to East due to pressure of Ottomans, had achieved these via sea. It would not be wrong to say that the capital obtained from these trips has been the most important factor in arising of Industrial Revolution, and the Industrial Revolution has also brought up the energy need increasing each passing day and the cheapest transportation of it in parallel to this.

The first pipe line transportation was used in Russia for the purpose of offering oil in 1863. This was initiated by the proposal of Russian inventor and chemist Dimitri Mendeleev. The pipe line transportation was pioneered by Vladimir Shukhov and Branobel Company near Baku between 1878-1880 (Kocakaya, 2013, p. 9).

Approximately, the pipelines passing and going to pass through Turkey which is a geographical bridge between Europe and Middle East and Middle Asia Countries having 40\% of world natural gas reserve and 67\% of world oil reserve, are of international importance (Yilmaz, 2005, p. 6), and the authors will try to compare Nabucco project with Trans Anatolian Natural Gas Line Project (TANAP), Trans Adriatic Natural Gas Pipe Line (TAP), and South Stream projects with advantages and disadvantages in this study.

\section{What Is the Nabucco Project?}

Nabucco pipeline has begun with the agreement signed between governments on Monday, 13 July 2009 in Ankara. It is a long transition pipeline transportation project planned so as to carry natural gas to European Union (EU) countries over Turkey. It is mostly supported by USA and EU for the purpose of being an alternative to the distribution made from Russia which is in the position of largest natural gas supplier for Europe. It is alleged that it has been interrupted substantially upon Russia announcing in the middle of 2007 that would sign natural gas purchase contracts in large amounts with countries (Kazakhstan, Turkmenistan) which are major natural gas suppliers of the line in Middle East. However, the project has gained power when German RWE Company became an equal partner to the Nabucco Company in February 2008. It has been expressed that the positive view of USA administration on the project's future is still continuing although the natural gas production required for the line to be profitable at full capacity can not be supplied also from this country as a consequence of an embargo still imposed on Iran, give to rise to big question marks about the line's future. Nowadays, the project has been changed as to start from the Turkey-Bulgaria border by taking the name of Nabucco West.

The 1,329 km pipeline Nabucco West, which will start from Turkey-Bulgaria border, is an adapted version of Nabucco Pipeline Project announced previously as to reach Baumgarten region of Austria from Erzurum. The aim of the Nabucco pipeline is to reduce source dependence by increasing natural gas supply diversity delivered to Europe ${ }^{1}$.

It is envisaged that Nabucco West would deliver to the Europe the natural gas taken by means of Trans Anatolian natural gas pipeline project from Shah Sea gas field depending on the decision to be made in 2013. It is expected to deliver 10-23 billion cubic meters gas via the line predicted to be completed in 2018. The line is also envisioned as a part of the Trans-Europe Energy Line of EU and EU funds have been utilized for

\footnotetext{
${ }^{1}$ Nabucco and TANAP merged (Retrieved from https://radikal.com.tr).
} 
feasibility and engineering studies. The total cost is 4-6 billion Euros according to the initial calculations.

The line will connect both Central Asia and Middle East as gas lines by merging with Trans Anatolian project in Standja region of Bulgaria, the gas taken from Trans-Anatolian Pipe Line and will merge with Baumgarten an der March Line which is the main natural gas carrier line of Austria at the west end. The updated project route is as follows (Retrieved from http://www.nabucco-pipeline.com/portal/page/portal/en/pipeline/route):

- Bulgaria: $424 \mathrm{~km}$;

- Romania: $475 \mathrm{~km}$;

- Hungary: $383 \mathrm{~km}$;

- Austria: $47 \mathrm{~km}$.

Nabucco Gas Pipeline International GmbH Company was founded in Vienna in 2004 for completion of the project. Current company partners are as follows:

- OMV (Austria);

- MOL (Hungary);

- Transgaz (Romania);

- Bulgargaz (Bulgaria);

- BOTAŞ (Turkey);

- GDF Suez (France).

GDF Suez has been included in the Project in 2013 through buying shares from OMV, following the transfer of shares of German partner RWE to OMV. In the past, French Gaz de France, Total and German E.N Ruhrgas, RWE companies also expressed that they want to be partners. It is notified that the participation of Russian Gazprom might occur in the future according to the status of the project.

\section{The Construction and Project Planning}

Russia, which has been meeting the need of Europe almost alone and wanting to guarantee the continuity of this situation for many more years, is putting pressure on the Central Asia countries which are the largest suppliers of Natural Gas particularly in the future, with political and economic attempts in respect of selling their gases only to itself. Sometimes the uncertainty in political situations of these countries is making ineffective the interventions from USA and Europe in the long term, undermining the efforts intended for breaking the Russian dependence in oil and natural gas sectors especially necessitating high cost investment in terms of the investor. In case of starting the project in 2010, it was scheduled to be completed in 2013, and even if sufficient gas is supplied, it is predicted that it would reach 10-23 billion cubic meters by achieving the full capacity after 2018. The Nabucco West project will be carried out over the engineering studies which have been already completed on the classic Nabucco route of $3,900 \mathrm{~km}^{2}$.

Meanwhile, Turkey wishing to be gas supplier without gas production rather than being a transit country in its territory, is waiting for strong support in this direction from Central Asia countries whose culture and language histories are common.

Reliable producers are surely needed for realization of the Nabucco project. A production agreement was signed which ends the process delaying the Turkish-Iranian Natural Gas Cooperation resulting mainly from

${ }^{2}$ Italian Saipem to perform Front End Engineering and Design services for Nabucco West (Retrieved from http://en.trend.az). 
distrust of Iran State and wished by Turkey for a long time, before Turkish and Iranian governments on 15 July $2007^{3}$.

The sales right of its production to other countries is also granted to Turkey which will operate one of the largest natural gas fields with approved presence in the world by the Agreement. Meanwhile, Iran finds the opportunity to increase the natural gas production which has been nearly come to a halt and to renew its technology without embargo. An agreement of great importance with regard to both countries has been signed. The agreement is expected to has a positive contribution in terms of diversification of the energy corridors on the future of EU. According to the statement of Nabucco Gas Pipeline International GmbH General Director Reinhard Mitschek, in case of a positive decision is taken by Shah Sea Consortium in June 2013, Nabucco West construction can be started in 2015 .

\section{Azerbaijan's Alternative Project Against Nabucco Is a TANAP}

A new road map has been drawn by Azerbaijan for itself which will start to market the gas produced by itself in a near future and Nabucco's experiencing difficulty in finding resource and having cost problems with countries which are going to supply resources can be enumerated among the reasons why Nabucco has been cancelled, which has been on the agenda lasting for 10 years and yet not completed. Meanwhile at the cost problem, repayments have been planned with the gas agreements that will be signed but these agreements could not be signed. At the same time, the reason behind the cancellation of Nabucco project due to its high cost, the project has collapsed because English BP, Norway's Statoil, and Azerbaijan State Petroleum Company (SOCAR) companies believe that energy prices are high in Italy and Greece which is the route of the gas to be transported to Europe and so it will increase costs.

When we look at the TANAP project, it is being planned to transport 16-21 billion $\mathrm{m}^{3}$ natural gas per year taken out from the Shah Sea upon the completion of pipe line project planned to be carried to Europe over Turkey. It is aimed especially to break the monopoly of Iran and Russia possessing the monopoly in Europe with this project. World Energy Council Turkish National Committee Chairman Süreyya Yücel Özden, in his assessment to the AA correspondent, said that it is important to explain clearly opinions of the countries which will supply the natural gas from Caspian region and will receive this gas and Nabucco has drifted into inconclusiveness due to the lack thereof. Özden continued such that:

For years, it has been much talked about. Who will supply natural gas, and how many, how will it be carried, how will it be transported to Europe? Nabucco now has dropped from the agenda which had been on the agenda for 5-6 years because of these matters could not be clarified as required somehow and the coordination could not be established fully between the consuming countries and producing countries. Instead, Trans Adriatic Natural Gas Pipe Line (TAP) and TANAP pipe lines came to the agenda. First of all, the attitude of Russia concerning these issues should be paid attention. And also which country will give the natural gas here in what quantity, this natural gas to be sold to which countries in South Europe including Greece and how much, these are important.

Özden, who stated that TANAP and TAP is going to be on the agenda instead of Nabucco, emphasized that it is required to take into account the economic crisis experienced by Greece among the countries took part in TAP. Özden, by stating that the selection of TAP and deactivation of TANAP are not important for Turkey, remarked that being selected of TAP instead of Nabucco is not a loss for Turkey. The important thing is TANAP's crossing over Turkey (Retrieved from http://www.aa.com.tr/tr/ekonomi/198695-onemli-olan-tanapin-turkiyeden-gecmesi).

\footnotetext{
${ }^{3}$ Iran-Turkey Energy Cooperation Agreement was signed, Hurriyet, 15 July 2007.
} 


\section{International Natural Gas Pipe Line Projects}

International Natural Gas Pipe Line Projects include:

- Nabucco Line: Nabucco Line;

- Russia-Türkiye DGBH (West): Russia-Turkey DGBH (West);

- Turkey-Greece DGBH: Turkey-Greece DGBH;

- Greece-Turkey DGBH: Greece-Turkey DGBH;

- Mavi Akım: Blue Stream;

- Trans Hazar Hatt1-Kazakistan: Trans Caspian Line-Kazakhstan;

- Ceyhan LNG Terminal;

- Shah Deniz Hattı: Shah Sea Line;

- Trans Hazar Hattı: Türkmenistan-Trans Caspian Line-Turkmenistan;

- Arap DGBH: Arab DGBH;

- Arap Gazı Hattı ile Misır Gazı: Arab Gas Line with Egypt Line;

- Turkey Iran DGBH: Turkey Iran DGBH.

\section{Nabucco Route}

The updated project route is as follows ${ }^{4}$ :

- Bulgaria: 424 km;

- Romania: $475 \mathrm{~km}$;

- Hungary: 383 km;

- Austria: 47 km (see Figure 1).

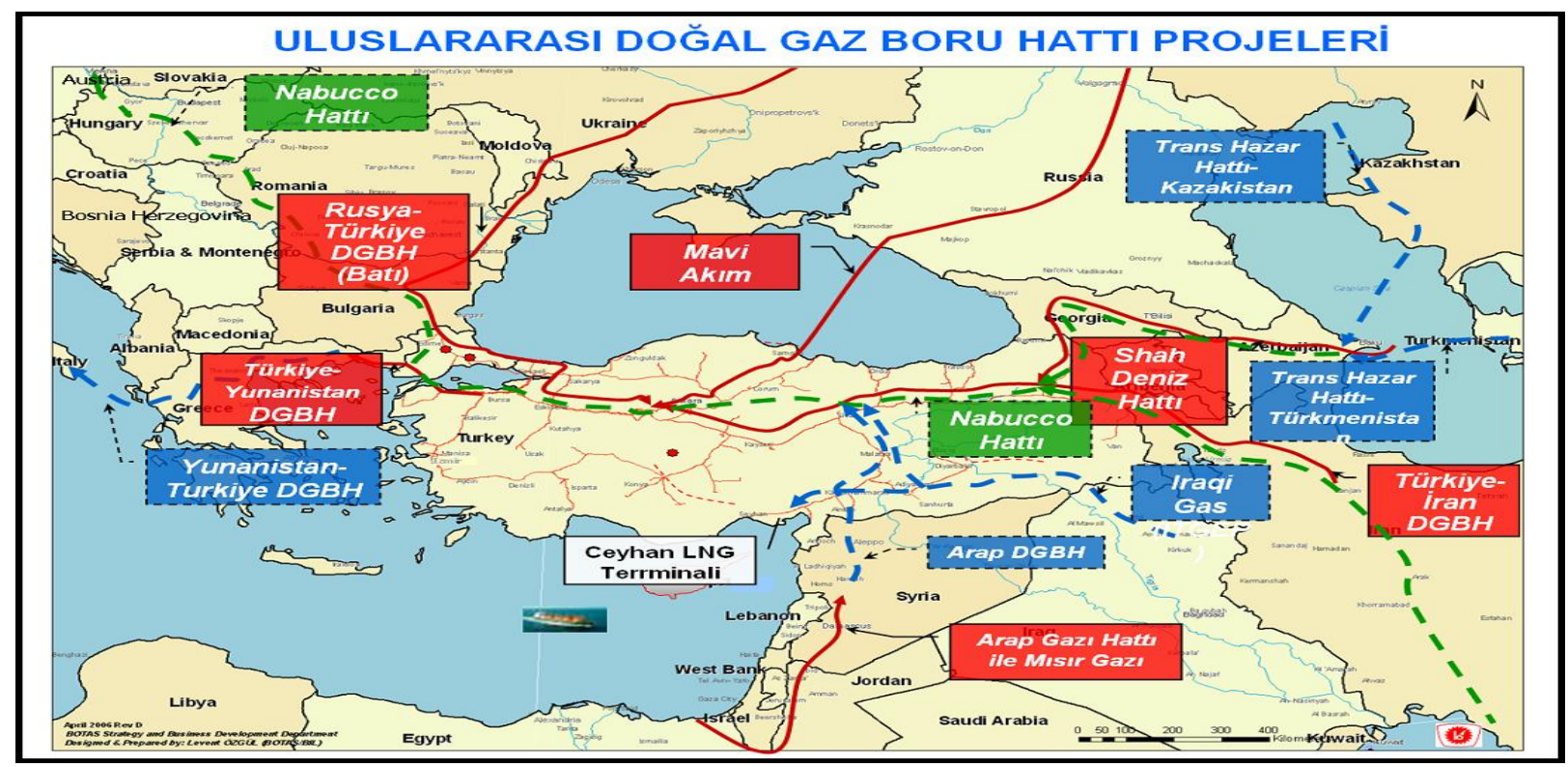

Figure 1. An overview of The TANAP and Nabucco routes.

\section{Discussions on First Gas Flow and Route of TANAP}

Azerbaijan SOCAR President Rövnag Abdullayev said that the distribution of first gas over TANAP will

\footnotetext{
${ }^{4}$ Retrieved from http://tr.wikipedia.org/wiki/Nabucco_Boru_Hatt\%C4\%B1_Projesi.
} 
be started in the year of 2019 .

Rövnag Abdullayev made this aforementioned explanation at the conference held within the framework of "Caspian Oil and Natural Gas 2013" fair which started in capital Baku nowadays. SOCAR President said that the 16 billion cubic meters natural gas to be taken out from Shah Sea basin will be transported at first stage upon activation of the line. Abdullayev added his remarks that the capacity of this line will be increased by supplying from other different explored basins later on.

SOCAR President expressed that the route after Turkey with regard to transportation of Azerbaijan natural gas to Europe will be clear late in the month. Upon activation of the line, Azerbaijan is going to possess an important position in point of energy safety also for Europe after Georgia and Turkey. Abdullayev, who gave information about available natural gas reserve of Azerbaijan, added his remarks that his country will produce 20 billion cubic meters natural gas per year in 2015. Meanwhile after the declaration of TANAP, two rival projects have emerged so as to meet the pipe line route at two European borders. The Nabucco West targets the east and middle Europe natural gas market starting from the Bulgaria border and TAP targets the south Europe natural gas market with a pipe line to be constructed underneath of the Adriatic Sea starting from Greece border. $^{5}$

\section{The Race Among TANAP, Nabucco, and South Stream}

Following the finalization of the natural gas extracted from "ShahDeniz" Sea of Azerbaijan would be transported with TAP, to its high cost English BP, Norway's Statoil, and Azeri SOCAR companies' reason - behind the cancellation process of Nabucco project also including Turkey is the high energy prices in Italy and Greece. Nabucco project did not have suppliers. The gas agreement to be signed for repayments has been planned but the agreement could not be signed. Russia finished the Nabucco project by signing South Stream Project with Italy, France, and Germany.

At the first time, Azerbaijan gas will be transported over the west border of Turkey with the TANAP project. It is aimed to ensure a price competition by removing the price monopoly of the Russian (Gazprom) gas which possesses the monopoly in Europe, transported to and used in Europe.

The emergence of TANAP pipe line project has disquieted Russia which possesses the Europe market with South Stream and other projects, and has regarded the project as a rival against the South Stream. From the beginning of the process, Russia, Azerbaijan, and Turkey all have said that projects or countries were not rivals. However, the seriousness of the competition can be understood at this point; Russian Gazprom Natural Gas Distribution Company has joined the privatization tender of Greek natural gas company DEPA, and afterwards Azerbaijan SOCAR Natural Gas Company has joined the privatization tender of DESFA Company which is responsible of internal pipe line of the country. Within this process, the visit of Greece Prime Minister Samaras to Baku, and afterwards the visit of Gazprom CEO to Athens show the competition in the process. Greece's choosing the Shah Sea II (TAP) has made the Nabucco project a thing of the past and Russia has guaranteed the South Stream project by enabling Bulgaria and Greece to remain in the process during the South Stream project.

When the authors look at these two projects, namely, South Stream and TANAP projects on the point of

5 
Turkey, Turkey wants to maintain oil and natural gas resources which are received from Russia and dependent thereof, at the same time it is seeking for new resources by reducing its dependence. When we consider the whole process, Turkey has signed TANAP, also has continued with South Stream project. In this case, Russia expressed its displeasure to Turkey under any circumstances within TANAP process which is deemed in competition with the South Stream project.

\section{Conclusions}

For the first time, Azerbaijan has enabled to transport its own natural gas with TANAP and TAP projects. When we look at the routes of these projects, South Stream and TANAP projects' routes do not coincide. Meanwhile, Turkey should take place in both two projects, namely, South Stream and TANAP projects, at the same time it should continue to buy the energy that is purchased from Russia and should protect its stability without damaging energy policies. It has been stated that the construction of South Stream project will be started at the end of 2012. In the event of the South Stream project's earlier completion and South Europe's filling the gas reserves as to meet, what will the TANAP project will be realized. These questions are required to be answered seriously.

\section{References}

Azerbaijan State Petroleum Company (SOCAR). (2013). President Rovnag Abdullayev (Rövnaq ABDULLAYEV). Retrieved July 9, 2013, from

http://www.21yyte.org/arastirma/enerji-ve-enerji-guvenligi-arastirmalari-merkezi/2013/07/01/7090/sah-deniz-neden-trans-ad riyatik-boru-hattini-secti

Farrére, C. (2001). Türklerin Manevi Gücü. İstanbul, Berikan: Adnan Şenel.

Kirpik, G. (2012). Haçlılar ve İpek Yolu. Bilig, 61, 173-200.

Kocakaya, M. (2013). Retrieved January 5, 2014, from http://prezi.com/uguzastha6wu/boru-hatti-tasimac/

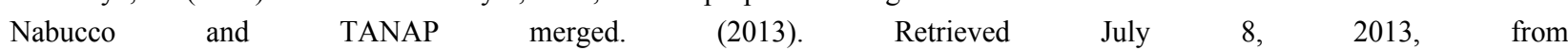
http://www.radikal.com.trhttp://tr.wikipedia.org/wiki/Nabucco_Boru_Hatt\%C4\%B1_Projesi

Yımaz, N. F. (2005). Petrol ve Doğal gaz Boru Hatlarına Bir Deneme. Tesisat Mühendisliği Dergisi, 87, 4-14. 